九州大学学術情報リポジトリ

Kyushu University Institutional Repository

\title{
Policy Analysis of the Liberalisation of the Rice Market in Japan
}

Breisinger, Clements

Department of Agricultural Policies and Marketing, University of Hohenheim

Yokogawa, Hiroshi

Song, Min

https://doi.org/10.5109/4519

出版情報: 九州大学大学院農学研究院紀要. 47 (2)，pp.503-531，2003-02-01. Faculty of Agriculture, Kyushu University

バージョン：

権利関係 : 


\title{
Policy Analysis of the Liberalisation of the Rice Market in Japan
}

\author{
Clemens BREISINGER*, Hiroshi YOKOGAWA and Min SONG
}

\author{
Laboratory of Agricultural Economics, Division of International Agricultural Resource \\ Economics and Business Administration, Department of Agricultural and Resource \\ Economics, Faculty of Agriculture, Kyushu University, Fukuoka, 812-8581 \\ (Received October 31, 2002 and accepted November 7, 2002)
}

\begin{abstract}
The Japanese rice market is an extreme example of national market protection in an industrialised country. As a consequence of these protectionist policies, domestic prices average almost 4 times the world market price for comparable rice qualities.

This paper discusses the obstacles on the way to political reform and to more openness of the rice trade. With the framework of a partial equilibrium model we quantify the benefits that can be expected by extensive trade liberalisation and show that the Japanese consumer and rice producers in developing countries largely carry the burden of the current system that only conserves the highly inefficient Japanese rice farming structure.

Our analysis shows that the current policies are economically not the best means to address the objectives targeted by the "new agricultural policy" of Japan that promotes mainly food security, multifunctional aspects of agriculture and the parity of rural- urban income distribution. On the contrary, the Japanese rice policy appears to use these arguments only as pretence to justify its protectionist interventions. As an alternative, we develop an example for the conversion to a direct payment system that targets the political objectives directly and improves the competitiveness of rice production in Japan.
\end{abstract}

\section{INTRODUCTION}

The beginning of the third millenium is characterised by an increasing worldwide integration of commodity, service and financial markets. In this process of globalisation, the international division of labour gains importance and the global exchange. of goods and services is increasing. However, the agricultural sectors in most industrialised countries are still highly affected by trade restrictions and national protection measures.

Despite multilateral negotiations under the General Agreement on Tariffs and Trade (GATT) and its predecessor the World Trade Organisation (WTO), little progress has been made in reducing trade barriers. This is especially true for the rice markets in East Asian countries like Taiwan, South Korea and Japan... Several policies are in place to protect the highly inefficient domestic producers. This might be especially surprising, regarding the fact that the very export oriented industrial sectors of these countries heavily depend on international trade and thus rely on the well functioning of international markets. However, agricultural production remains a sensitive issue in most countries and for Japan, rice is in many respects of outstanding significance.

Regarding the increasing pressure under the upcoming WTO Negotiations, one of the most serious and urgent policy questions facing the Japanese administration is how to

\footnotetext{
* Department of Agricultural Policies and Marketing, University of Hohenheim (e-mail: breisingę@@gmx.de)
} 
reform the domestic rice system. The need for policy changes raises the question of alternatives and requires assessments of the effects that can be expected by political reform.

The paper is structures as follows: Chapter 2 gives in its first part an overview of the domestic rice production and the rice market in Japan in the context of the global rice market. Peculiarities of the Japanese consumer preferences for japonica rice as well as the special cultural background of rice are subsequently considered. Furthermore, the main problems of the Japanese rice sector are outlined as a basis to demonstrate the need for reform. Secondly, the political framework both domestically and internationally is analysed. The presentation of the target system of Japanese rice policies is followed by an analysis of the rice market support system with its two major elements, the import regime and production support. At the end of the chapter, the current agricultural policy of Japan is confronted with international trade agreements and domestic societal developments to show the extent to which Japan has adapted its policies to the changing requirements.

Chapter 3 shortly presents the analytical framework used to determine effects of trade liberalisation. The presentation of the theoretical arguments in favour of free trade is followed by a quantitative analysis of the welfare effects on producer, consumer and the government budget under a free market scenario and a partial liberalisation scenario. Chapter 4 expands the discussion beyond pure welfare economics. The effects on the inter- and intrasectoral income distribution, rural areas and the environment as well as on international trade are considered. In chapter 5 direct payments are analysed as an alternative to current policies.

\section{CHARACTERISATION OF THE JAPANESE RICE SECTOR}

\section{Domestic Rice Production}

Under the climate of the East Asian Monsoon, which is characterised by hot summers and heavy rain, rice, originally a tropical marsh crop has become a predominant food crop in Japan. Since neither other crops nor livestock raising had developed effectively as alternative food source until recently, a stable and sufficient supply of rice is seen as directly related to people's livelihood and to the security of the nation (OECD, 1987, p. 35 ). History tells that rice shortages and price rises had often triggered riots until some 60 years ago. The rice price has long been regarded as one of the leading indicators on which the price of almost all other commodities and wage rates would be based. Further more it is often asserted that the Japanese mentality and culture has been fostered through paddy rice farming, which requires hard work in muddy fields under the summer heat and close cooperation among village inhabitants with respect to water control and labour sharing during the time of the transplanting and harvest (OECD, 1987, p. 35).

As in most developed countries, the agricultural production in Japan is of minor importance when compared with the whole economy. In 1997, the gross value of agricultural output was 10.2 trillion yen, about 2 per cent of Japan's total GDP (Worldbank, 2001). The gross value of agricultural output in Japan was rising until the mid 1980's. It then stabilized, before declining gradually over the last decade. Although the rice production has been declining over the past years as well, rice still is a basic commodity in Japan and accounts for more than 30 per cent of the total value of agricultural output. 
The total amount of land under cultivation in Japan in 2001 was 4,794,000 ha, which is only 13 per cent of the total land area. Paddy fields represented 55 per cent of total cultivated land. The land under cultivation in Japan decreases in number continuously with the main reasons being the conversion to residential property and the abandonment of cultivated land.

The number of farm households in Japan has constantly declined since 1960, the point in time that saw the nation's rapid economic growth hit full stride. In 2000, Japan had about 3.12 million farm households, roughly half the corresponding number for 1960 (6.06 million). Like illustrated in figure 1, for only 25 per cent of the farm households farming activities constituted the main business, which means that 14 per cent were engaged exclusively in farming operations for their livelihood (professional farmers) and 11 per cent had additional income from other sources that did not exceed their income from farming (semi-business). 75 per cent of the farm households can be classified as part-time with a non-farm income that exceeded their farm income. Among this group a remarkably 25 per cent did not participate in the market.

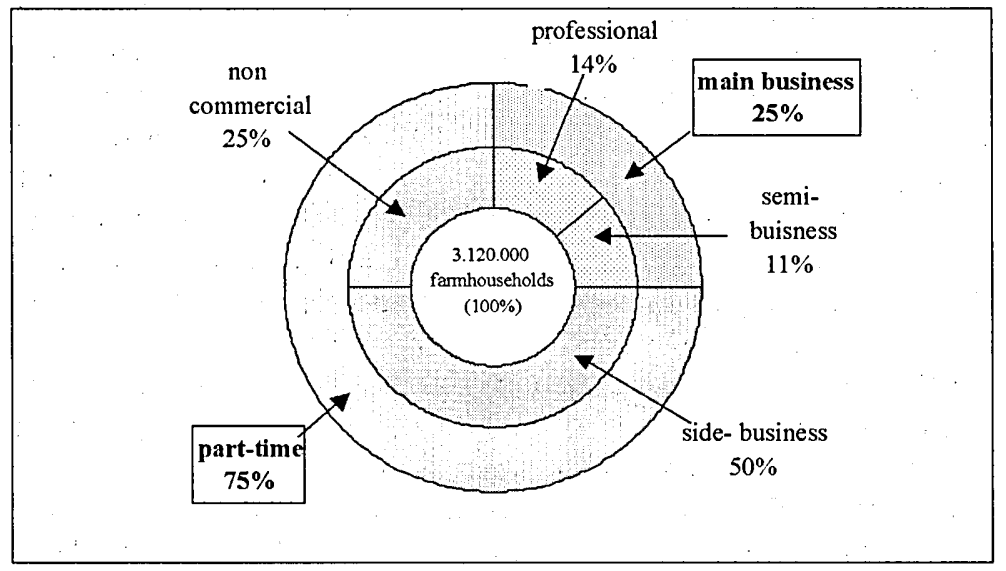

Source: MAFF 2000

Fig. 1. Farm household classification.

For rice farming households the share of part time employment is even higher. In 2000 rice-growing households numbered 2.3 million, of which 1.8 million (or 58 per cent of the total number of households) sold rice on the domestic market. A significant proportion of them is very small-scale. 60 per cent of rice-producing households have less than 0.5 ha, reflecting the suitability of rice as a crop for farmers cultivating extremely small plots of land and working principally off the farm. With mechanisation, rice has become a convenient crop that can be produced by the aged and female members of farm households while enabling the younger male members to work off the farm and the household to retain its most valuable asset-its farmland (George, 2000). Another major reason for the small-scale structure can be found in the Japanese agricultural land law of 1952 . This 
law stressed the principle that "farmland should be owned by those who actually cultivate it" (Fujiki, 1995, p. 8). The law even imposed an upper limit on the ownership of farmland ( 3 ha in non-Hokkaido-region and 12 ha in the Hokkaido-region). Moreover the law also determined that in principle landlords could not terminate the land lease contract apart from the case that tenants refused to pay rent for no reason. The law was basically guided by the American strategies against possible communist revolution (Fujiki, 1998, p. 3).

However, Japan's agricultural labour force stood at about 3.89 million individuals in 2000 , whereas senior citizens accounted for over half of the total agricultural workforce. 52.9 per cent of all agricultural workers were aged 65 years and over.

Improved yields and high levels of support kept rice production in Japan in the 1990's at around an average of 10 million tons a year until 1997, which led to a massive oversupply situation. The yields for rice per ha averaged 5.24t (MAFF, 2000). However, production has been lower in 2001 with a domestic output of 9.057 million tons. But the over supply situation remained and rice surpluses have become a long-term problem. According to MAFF calculations the average production cost of rice in Japan was 251,777 yen per ton, whereas the most important cost position was the cost for labour with 104,466 yen per ton. Cost reductions through technological progress have been limited to less than 1 per cent in the period from 1985 to 1995 and a substantial reduction would have to come almost entirely from economies of scale (Boonekamp, 1995, p. 25). In fact, production costs decrease substantially with the farm size. Farmers with over 5 ha of land were able to produce rice for 225,000 yen per ton and the production costs of farmer with over 10 ha decrease to 213,816 yen per ton (MAFF, 2001b). To reach international competitiveness however, estimates proceed on the assumption that Japanese rice production would need an average farm size of 50 ha (George, 2000, p. 25). Besides effects derived from economies of scale, a substantial reduction of the production costs can also be expected from labour extensive production alternatives like the direct sowing system instead of the transplanting system currently used by most of the Japanese rice farmers (Personal Interview with Professor Murata, T. at Kyushu University, Fukuoka, 2002).

The productivity performance of the Japanese agricultural sector in terms of labour productivity is very low. According to Meer and Yamada (1990, p. 129), the productivity of labour in Japan in the arable sector compared with the Netherlands was five to seven times lower and in the early 80 ies Japanese farmers produced little more than $10 \mathrm{~kg}$ paddy per hour in contrast to US farmers who produced about $500 \mathrm{~kg}$ (Meer and Yamada, 1990 , p. 152). Summing it up, the negative value added for rice at international prices underlines that rice is a crop for which comparative advantage is extremely low in Japan and it can be assumed that among the various government policies in Japan, rice policies have been most harmful for achieving productivity increases.

\section{The Rice Market}

Rice is the most widely used food grain in the world. Production and consumption are concentrated in Asia, Northern Africa and Middle Eastern regions. : About 90 per cent of the worlds rice is produced in Asia and over one half in a band from Pakistan, South and East Asia through the Philippines. Only 6 per cent of the global production is traded on the world market compared to 18 per cent of wheat and 20 per cent of soy beans (FAO, 2001). Total volume of global rice trade has grown to more than 20 million tons per year 
(figure 2). The small amount of rice traded relative to the amount produced provides potential for highly variable world prices resulting primarily from shifts in exportable supplies in the major exporting countries and for domestic production short falls in large consuming countries. There are two main reasons for the very limited volume of rice trade. Firstly, rice is only of very limited importance in the diet of developed countries and secondly most of the developing countries in East Asia, where rice is a staple food item, have a self-sufficiency policy.

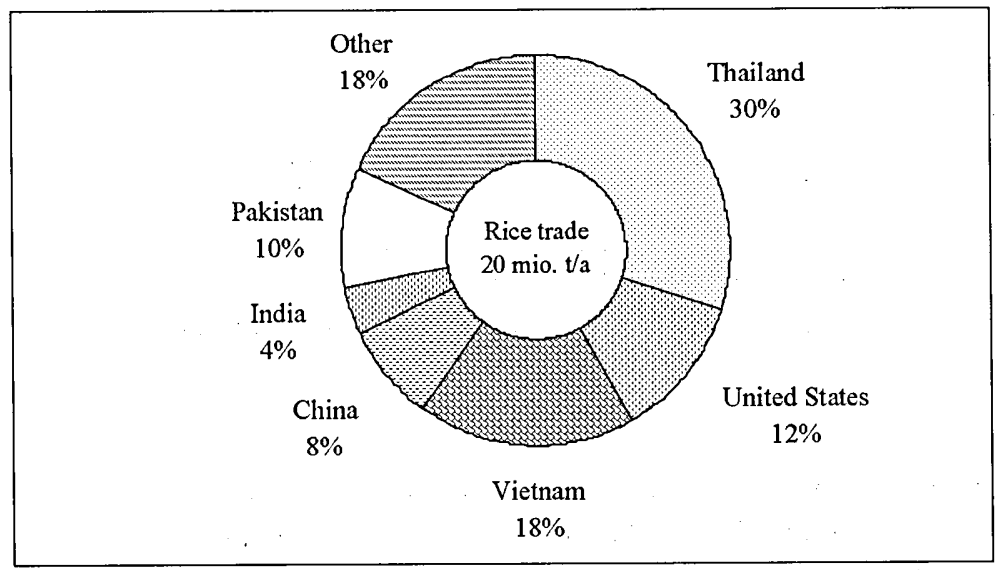

Source: FAO 2001

Fig. 2. Export shares for rice by countries.

For food security reasons, these counties aim at maintaining a close balance between domestic supply and demand, importing any shortfall and exporting any surpluses (Boonekamp, 1995, p. 27). Furthermore, the international rice market exhibits greater price volatility than other grain or oilseed markets because of the importance of rain fed monsoon and the segmentation of rice into different types and qualities. As a result of gradual increases in population and steady economic growth in the regions, worldwide rice consumption has increased faster than production, resulting in slight increases in the price of rice in the world market in the last decade. Most important to the rice sector in Japan is the fact that rice varieties and types segment the rice market. 75 per cent of global production is of the Indica type, 10 per cent of Japonica type-that is characterised by its round and short shape and sticky taste when cooked-and 15 per cent remainder (figure 3).

Almost all rice produced and consumed in Japan is Japonica rice. Japan's imports averaged around 600,000 tons of rice over the past few years and therefore account for a disproportional large share of the value of world Japonica rice trade (Dyck, 1999). Despite the fact that domestic consumption concentrates on Japonica rice, 600,000 tons of the 700,000 tons imported in 2001 was of the Indica or "other" type.

The major customers for Japonica rice are Japan, South Korea, Turkey, Jordan and 


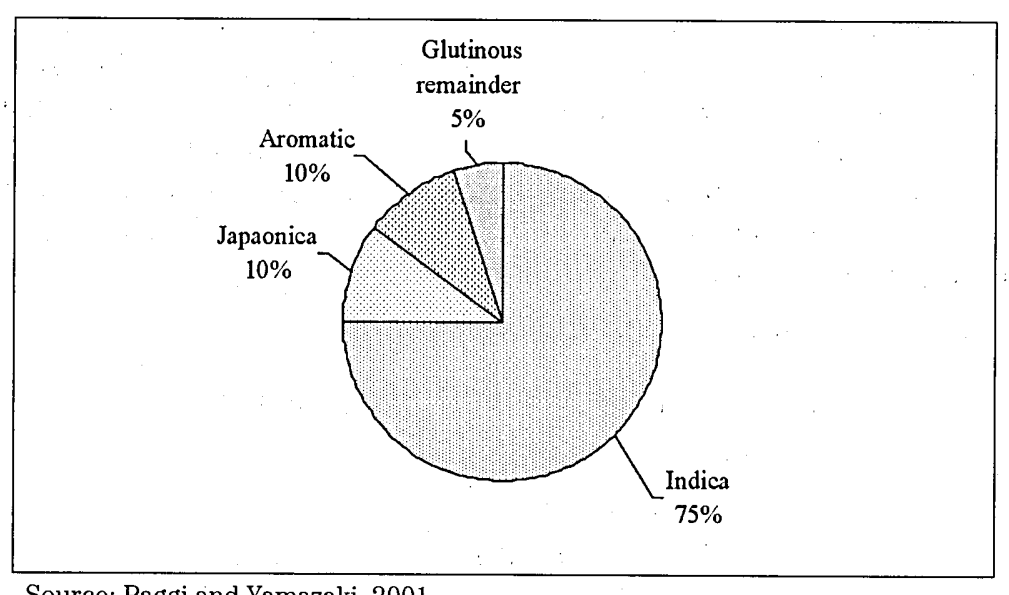

Source: Paggi and Yamazaki, 2001

Fig. 3. Segmentation of the world rice market by types.

Canada. Their share was about 90 per cent of the total world trade volume of 1.5 to 2.5 million tons (Paggi and Yamazaki, 2001), whereas the major export competitors for Japonica rice are China, USA, Egypt and Italy. The main exporters for Indica rice to Japan are the United States, which supplied almost 50 per cent in 2001, followed by China and Australia (Paggi and Yamazaki, 2001).

On the production side, Japan has been the second largest producer of Japonica rice only surpassed by China. China produced 33.1 million tons annually in the 1995 to 1997 period, which is much smaller than the production of Indica rice (95million tons) and its production of Japonica rice is projected to increase by 17 per cent by 2010 , which is faster than the production growth rate of Indica rice (Paggi and Yamazaki, 2001).

According to the results of a model of Koo and Taylor, the world price of Japonica rice under a trade liberalisation scenario, in which Japan and Korea liberalise its rice imports, is expected to increase by 19.7 per cent (Koo and Taylor, 1999, p. 6). In this case of a substantial market opening it is expected that the US and China expand their Japonica rice production while other countries will not be able to do so in the short term, mainly because those countries have produced only Indica rice and have limited capability to switch to Japonica rice production due to a lack of experience and knowledge. However, it can be assumed that it would not take long before access possibilities to the high priced Japanese market would stimulate the supply of Japonica rice in these countries. If problems related to poor infrastructure can be overcome, substantial export supply potential would seem to exist particularly in certain Asian countries like Vietnam (Boonekamp, 1995, p. 29).

Domestic demand for rice in Japan comes mostly from two groups: from the private consumer and the processing industry. Japanese private households have so far stuck exclusively to the Japonica rice produced in Japan. One reason is the price for foreign rice is still not low enough to attract consumers. Second and more importantly is that the 
availability of foreign rice is very limited. However, opinion surveys suggest that Japanese consumers are prepared to pay a premium for domestic quality rice (George, 1990, $\mathrm{p}$. 121).

Table 1 gives a detailed overview of the development of consumption expenditures. With an average yearly income of 5.61 million yen and total expenditures of around 740,000 yen for food, Japanese consumer spent about 13 per cent of their income for food in the year 2000. One of the main reasons why Japanese consumers have such tolerance for high rice prices is because rice expenditures represent just 4.4 per cent of the household budget. According to A. George, Japanese consumers are easily convinced that, for reason of quality, national security, safety, environmental preservation and such import liberalisation is not worth fighting for.

Table 1. Private consumption expenditures in Japan from 1985-2001(yen/year/person)

\begin{tabular}{lrrrrrr}
\hline & \multicolumn{1}{c}{1985} & \multicolumn{1}{c}{1995} & \multicolumn{1}{c}{1997} & \multicolumn{1}{c}{1999} & \multicolumn{1}{c}{2000} & \multicolumn{1}{c}{2001} \\
\hline Consumption expenditure (yen) & 273,114 & 329,062 & 323,008 & 323,008 & 317,133 & 308,692 \\
Expenditure on food (yen) & 73,735 & 77,886 & 78,306 & 76,590 & 73,844 & 71,543 \\
Expenditure on rice (yen) & 6,147 & 4,404 & 3,947 & 3,634 & 3,404 & 3,113 \\
\hline
\end{tabular}

Source: Ministry of Management, Home Affairs 2002

Demand for processing rice averaged 1.3 million ton from the period of 1996 to 2001 per year or about 15 per cent of total demand. The major part went to the production of sake (from $500,000 \mathrm{t}$ to $380,000 \mathrm{t}$ in the period), spirit (70,000 t to $80,000 \mathrm{t}$ ), rice cracker $(230,000 \mathrm{t}$ to $210,000 \mathrm{t})$, sweets $(130,000 \mathrm{t}$ to $140,000 \mathrm{t})$, Miso paste $(150,000 \mathrm{t}$ to $120,000 \mathrm{t})$, frozen rice $(80,000 \mathrm{t}$ to $150,000 \mathrm{t})$ and rice cake $(50,000 \mathrm{t})$ (MAFF, 2002). As the rice manufacturing does not depend on the kind of rice, all rice varieties can be used. This fact is especially important as almost all imported rice to Japan is of the Indica rice variety and is directed to the food processing industry $(600,000 \mathrm{t}$ in 2001). This shows that the Food Agency avoided putting foreign rice directly into the market of private consumption. Another important fact is that the total demand of the processing industry could take a further $700,000 \mathrm{t}$ of imported rice off the domestic rice market.

However, the total demand for rice has been constantly declining since the 1960's and it continued to decrease during the reference period. According to MAFF's latest "Food Balance Sheet" (MAFF, 2001b) the average annual per capita consumption dropped constantly from $74 \mathrm{~kg}$ in 1985 to $64 \mathrm{~kg}$ per capita in 2000. This drop in rice consumption is mainly due to the diversification of eating patterns of Japanese consumers and the downward trend of traditional rice consumption is likely to continue as the younger generation prefers to spend less time washing, steaming and cooking rice facing a wide variety of carbohydrate alternatives such as pasta and bread (Oryza, 2002). As a consequence, the Japanese government promotes the consumption of rice, which it sees as important for a healthy diet, and improving the self-sufficiency in food according to the "Dietary Guidelines" (MAFF, 2001a). While the income elasticity for rice will decline as income increases, only Japan among some other high income countries such as Malaysia, Singapore, Taiwan and Thailand have income levels that support negative estimates of 
income elasticities for rice (Huang, David and Duff, 1991).

When talking about rice prices in Japan different kinds of internal and external prices must be distinguished. As they are strongly related to political decisions and institutions rather than to market forces they are discussed in the context of the rice market support system.

\section{The Rice Market Support System}

In order to attain the objectives of trade policy, the government has available a wide range of measures. In the following the core measures forming the rice market support system in Japan are subsequently discussed and graphically illustrated.

Generally the political decision makers have in the first place relevant laws and administrative regulations. There are three groups of laws: general laws (e.g. foreign exchange and foreign trade control law, export and import transactions laws), customs laws (e.g. customs tariff law) and other trade related laws (e.g. food security related laws). The general laws stipulate the aims of the legislation as being to enable proper expansion of Japans external transactions with necessary but minimal control on the basis of freedom of foreign exchange, as well as to contribute towards the sound development of the national economy (OECD 1987, p. 19). Foreign trade laws in Japan include import quotas and tariffs. Other laws concerning rice trade in Japan are the "law concerning standardisation and proper labelling of agricultural and forestry product", the "product liability law" and the "temporary measures law".

Monetary and fiscal policies can influence agricultural trade in two possible ways, direct and indirect. Direct measures are for example on the supply side financial assistance for investment or budgetary support to the agricultural sector. As a more indirect channel, one can point to macroeconomic measures effecting exchange rates and thereby export and import structure in the agricultural sector. Generally speaking, a low value of the yen has the same effect as a tariff in the sense that it makes the Japanese market less attractive for foreign exporters. It is behind the scope of this paper to describe the totality of Japans fiscal and monetary policies. Rather, in order to provide concrete and practical information on rice policy, stress is put on the direct policy measures concerning the rice system.

A crucial factor. when it comes to agricultural policy is the cost arising from various support measures. In 2000 the total budget of the Japanese government amounted to 898,125 trillion yen: The share of the agricultural budget was 3.2 per cent or 2,874 trillion yen (MAFF, 2001b). From that, 606.7 billion or 21 per cent were directly related to rice policies. General support that benefits farmers like tax concessions are not accounted for separately for rice. However, money spent for agricultural support was 22,720 yen per inhabitant or 890,000 yen per farm household. Compared to 11,400 yen and 600,000 yen in the EU (15) and 27,300 yen and 4,040,000 yen (USDA, 2001) in the US, the level of money spent for agricultural support does not seem extraordinary high in Japan, but it neglects the fact that a high percentage of agricultural support is derived from border measures and thus carried by the consumer. In fact, agricultural support policies in Japan are designed so that Japanese consumers pay almost for all domestic support. .In 199953 per cent of the amount spent by consumers in Japan on agricultural commodities consisted of support to domestic producers. For rice 85 per cent of the value of the product 


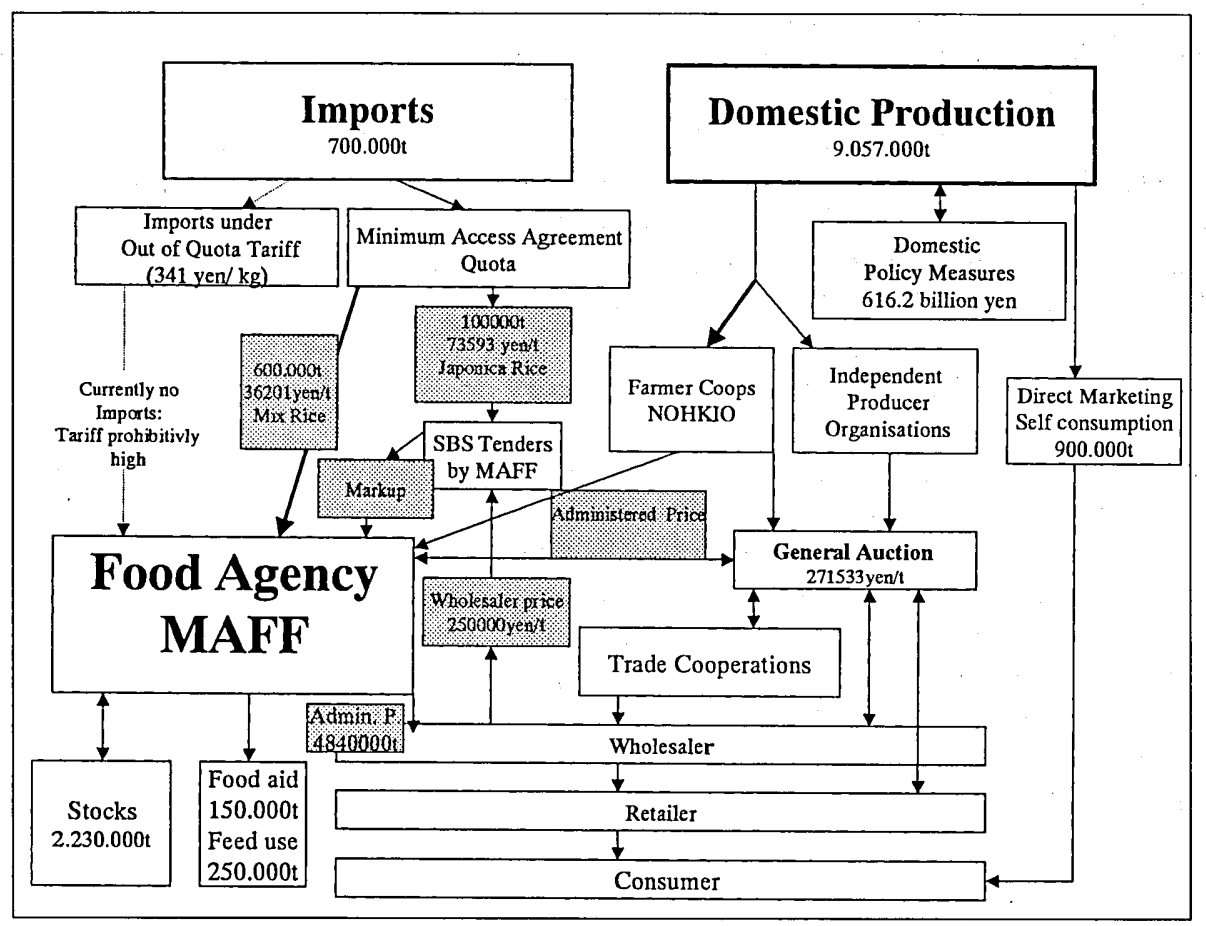

Source: own formation

Fig. 4. The Rice Market Support System of Japan.

consumed was made up of price support above world market levels (OECD, 2000).

Key policy measures for rice are besides the border measures various domestic support measures. Figure 4 might be used to analyse the present rice support system in Japan.

The system is based around the Japan Food Agency (FA), which functions as a state trading enterprise. The Food Agency is part of the Japanese MAFF and deals exclusively with rice and wheat. In fact the FA controls the whole rice sector in different ways:

Control of external trade via minimum access quota and tariffs

Domestic production control through land diversion and set aside schemes

Determination of the governmental rice price (purchase and the sell prices)

$>$ Control over government stocks

1) Import Regime. Until 1995, Japan had maintained an effective ban on rice imports, which rested on the exclusive right of the Food Agency to conduct trade in rice. Under this state-trading regime Japan imported rice only if domestic production failed to satisfy consumption needs. When it joint the GATT in 1955, Japan claimed the right to regulate trade in rice and some others commodities under GATT's "Balance of Payments" (BOP) clause that granted concessions to countries with trade deficits. But in 1963 Japan did not qualify for the BOP rational for trade barriers any longer as the trade balance went 
from deficit to surplus because of the increase in export of manufactured goods. However, Japan maintained some trade barriers such as those for rice and beef, which were to be lifted at an unspecified time (Boonekamp, 1995, p. 21).

The Uruguay Round (UR) of GATT negotiations focused particularly on barriers on agricultural trade and in general to "tariffy" non-tariff barriers -i.e. to substitute tariffs on imports for fixed quantitative limits to trade. However, negotiating countries agreed to exceptions under conditions spelled out in Annex 5 to the UR Agreement on Agriculture (URAA). It provides that a developed country such as Japan will allow minimum access for imports in the first year of URAA commitment equal to 4 per cent of average annual consumption in the UR base period, 1986-1988. This rises in annual increments of 0.8 per cent of the base-period consumption until it reaches 8 per cent in the final year. Japan first year of URAA commitment was Japanese Fiscal Year (JFY) 1995 and the final year is 2000 , with quantities of required imports rising from 379,000 tons to 758,000 tons in 2000 . However, Annex 5 of the URAA also allows a developed country to tariffy its imports barriers (convert an import ban or quota to an import duty at the beginning of any year). Subsequently, Japan announced that it lowers annual market access increases in 1999 and 2000 from 0.8 per cent of base -period consumption to 0.4 per cent on April 1st 1999. While Annex 5 requires that Japan continues to meet its existing minimum access amount (606,000 tons in 1998), the smaller increases in minimum access will put the input quota in 1999 at 644,000 tons instead of 682,000 tons, and in 2000 the quota will be 682,000 tons instead of 758,000 tons until another agreement is made. Furthermore, under URAA, countries were required to reduce tariffs by 36 per cent. However, the exception was made for "important" commodities, where the tariff had to be reduced by only 15 per cent. This regulation was applied by Japan for its rice sector.

Under the Minimum Access Agreement (MAA) imports in 2001 amounted to 700,000 tons, thus adding considerable amounts of rice to the already severe oversupply situation in Japan. Two different channels under the MAA must be differentiated: most of the rice reported $(600,000$ tons) is directly purchased by the Food Agency. This amount contains a "rice mix" most of it being of the Indica rice type or rice of minor quality. In the 2001 purchase tenders, C.I.F. rice prices in successful bids ranged from 23,981 yen per $\mathrm{kg}$ to 40,319 yen per $\mathrm{kg}$. The average purchase price in 2001 was 36,201 yen per ton. The imported rice is usually stored for 12 months before it is released for purposes such as food aid, feed use or processing. As a consequence, the vast majority of the imports of rice to Japan do not affect the domestic market directly. However, the extra quantities would increase effective import demand and could have an impact on world prices. But rice diverted to food aid does not compete in the domestic market and therefore does not reduce the market distortions in Japan arising from the highly regulated and protective arrangements. The second and less important channel in terms of quantity are imports under the MAA, which are conducted via "Simultaneous Sell and Buy" (SBS) tenders. In an SBS, private sector buyers and sellers can negotiate directly to determine the quantity, quality, timing, etc. of a sale. In the Japanese SBS system, buyers and sellers propose a quantity and price of rice to be exchanged. The Food Agency examines all bits, choosing those that have the widest margin between the proposed selling and buying prices. The agency keeps the margin. The margin is the mark-up, which under the URAA cannot exceed 292 yen per $\mathrm{kg}$. The closer the margin gets to 292 yen per $\mathrm{kg}$, the more likely the 
Food Agency will accept the bid, so buyers and sellers bids reflect pressure to maximise the difference. However, at some price buyers will loose money if they cannot dispose over the imported rice within Japan and recover at least the SBS purchase price. In JFY 2001 (April 2001 to March 2002) four SBS tenders and six Ordinary Minimum Access (OMA) tenders were held. The mark-up for wholegrain rice sales was about 180 yen per $\mathrm{kg}$. This fact indicates that the highest marketable addition to imported rice prices-whether mark-up or other addition such as tariff - is currently around 180 yen per kg, and current market conditions would clearly not support over quota sales with an added 341 yen per $\mathrm{kg}$ tariff. Nor would a reduction of 50 per cent of the present tariffs to 170 yen per $\mathrm{kg}$ be enough to stimulate over quota trade substantially, as will be explicitly demonstrated in chapter 4. In 2001 the price per ton of Japonica rice in SBS averaged around 73.950 yen and with the mark up entered the domestic market around 250.000 yen.

For imports above the minimum access amount, Japan has specified a tariff of 341 yen per $\mathrm{kg}$. The effect of the tariff (equivalent to about 2800 US\$ per ton at 2001 average exchange rate) depends on the price of imported rice relative to domestic. Using 2001 prices (C.I.F.) for regular Minimum Access imports, the tariff of 341 yen per kg will raise the average per $\mathrm{kg}$ price of Japonica rice to 415 yen from 74 yen and the average Indica to 397 yen per kg from 36 yen per kg. In contrast, Japan's average Japonica rice sells at wholesale for 271 yen per kg. However, since Japan sets its tariff in yen, the effect of the tariff on trade varies with the exchange rate. The rise of the yen from 360 yen per US\$ the fixed rate prevailing in the 1970's - to rates as low as 80 yen per US\$ in 1995 made Japanese rice much more expensive compared with imported rice. In 2001 the yen ranged from 116 yen per US $\$$ to 127 yen per US $\$$ and averaged 122 yen per US\$ (Bank of Japan, 2002). There were no imports under the current tariff level of 341 yen per $\mathrm{kg}$. Given that tariff level at 341 yen per kg Japanese buyers are unlikely to import any rice in the future. With a very strong yen US and Chinese rice may be competitive with Japanese varieties.

In addition to the tariff on over-quota imports, the Japanese government reportedly also plans to implement a special safeguard mechanism. One version of this proposal which has not been officially announced by the time of this report, states that if over-quota imports exceed 30,000 tons, or if imported rice prices fall below 90 per cent of the average for 1986-1988, an addition tariff of 117.6 yen could be imposed (Bull and Roberts, 2001, p. 20).

The world market price for rice differs largely between the Japonica rice type and other imported rice types. For the calculations in chapter 4 the average results from the SBS tenders for Japonica rice were used to determine the c.i.f. price of Japonica rice. As over 80 per cent of this type is provided by China and USA, only imports from these countries were taken into account. Those prices are largely the outcome of international market forces and include freight to Japan. However, theses prices might be slightly disturbed by the fact that Japan selects heavily among it trade partners. To determine the average price of Indica and "others", the average of all six tenders held in 2001 between the FA and the importers was calculated. For the Indica and others the c.i.f price was 36,200 yen per ton, whereas the price of Japonica rice was 73,590 yen per ton in Japan. The following figure 5 gives an overview of the different rice prices relevant for Japan in 2001. 


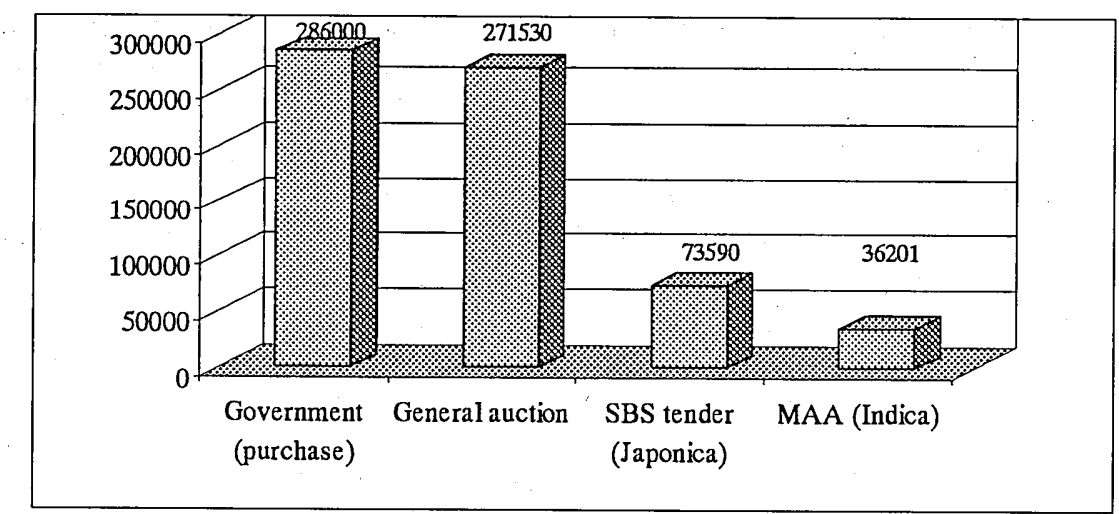

Source: MAFF Agricultural census, own calculation

Fig. 5. Prices for domestic and imported rice in Japan (2001).

2) Domestic Support. The Food Agency also plays a role in domestic rice marketing. Although the influence of the FA decreased in the last years due to smaller amounts of domestic rice purchased by the FA and the increasing significance of the general auction system, the domestic market cannot be called a free market. Two major categories can be differentiated in the Japanese domestic rice distribution system. Orderly marketed rice (government marketed rice plus voluntarily marketed rice) and non-orderly marketed rice (e.g. rice farmers own consumption and rice sold directly to wholesalers, retailers and consumers). Orderly marketed rice occupies most of Japan's total demand for rice. The majority of the yearly rice production (government marketed, voluntary marketed) is sold by farmer's co-operations -which most important representative is called Nohkio- and independent producers organisations via general auctions. The rice price of the general auction between producer cooperatives and wholesaler organisations averaged at 271,533 yen per ton in 2001 and thirteen auction were held all together. The prices differed substantially between regions whereas the average price between the outcomes of the comparable auctions did not differ a lot. The highest average price of all auctions reached was 281,280 yen per ton and the lowest outcome was 262,230 yen per ton. However, it is important to remember that this price depends on a mix of market forces and political influence. The Food Agency can influence the domestic trade by actively participating in the auctions as buyer as well as seller of rice. In the beginning of each year MAFF determines, depending mainly on production cost calculations conducted by MAFF itself, the purchase and sell-price for rice, which becomes an important indicator for the general auctions held between producer organisations and trade co-operations. Until 1987 the price at which the Agency purchased the rice was higher than its sell price. After 1987 the situation was reversed mainly due to increased overproduction and decreased demand.

The stockpiling of rice finally is a buffer for the Food Agency to store its purchased rice (imported and domestic) and dispose it in different ways. The government currently aims to replace rice stocks each year. According to a MAFF proposal in 2001 the appro- 
priate level of stock target will also be reduced to one million tons from actual level of 2.23 million tons in 2001 , because the cost of storing rice for a year is substantial. Total cost for keeping governmental stocks are discussed in the following section.

3) Domestic Production Support Measures. The above described import regime is supported by domestic policy measures for the rice sector. The total amount spent from the government budget towards rice support was 616 billion yen in 2001 . Support that is generally directed to all farmers regardless of their production scheme, such as tax concessions and retirement payments, could not be identified separately. However, those payments are of minor importance and constitute for less than five per cent of the rice budget (Personal Interview with Professor Murata, T. at Kyushu University, Fukuoka, 2002).

Table 2 shows the different schemes and programmes directly related to the rice sector for the years 2000 to 2002 . Major policy measures can be divided in five groups. Production support measures, marketing policies, support for the processing of rice, consumption measures and measures related to the disposal of over supply rice.

The first group mainly contains programs for structural improvement (1-9), supply control $(10-13,15)$ and income stabilisation (14). The most important measure of structural policy with 101.3 billion yen is the program for "the structural adjustment of farmland" (4), which mainly includes the reallocation and consolidation of arable land and measures to improve arable land such as construction and maintenance of irrigation channels and paddy field dams. The supply control is conducted with the Acreage Reduction Program (ARP). Programs related to the supply control contain the schemes from 9 to12. Even though the ARP is technically a voluntary supply control policy there is 100 per cent participation in the program. In 2001 a historic level of over 1 million ha, about 40 per cent of Japan's total potential rice paddy land, were set aside. This includes diversion to general crops such as soybeans, wheat, barley and feed grains, diversion to permanent crops for landscape conservation, conservation of paddy fields without cropping, diversion to specific crops such as vegetables, land improvement during the production period and conservation management. The subsidy per hectare for diverted land averaged around 13,000 yen in 2001. A model of Suzuki and Kaiser (1998) estimates farm revenues with and without the ARP. Results indicate that the system enhances farmer's revenues by 600 to 1,000 billion yen compared with a no supply control policy. However, direct payments for land diversion were 66.8 billion yen (9). Additionally position No. 10 is also directly related to the land diversion. As there are discrepancies between areas in the total percentage of diverted land (Hokkaido region has the highest participation rate in the program with 45 per cent), the mutual compensation system is a fund that provides farmers that have higher set aside ratios than others with compensation money. In this scheme, basically all farmers pay 30,000 yen for each ha of their paddy field land into the fund, whereas the government contributes 75 billion yen into the fund that is then redistributed among the farmers according to their participation in the program. In 2000 the "system of direct payments in hilly and mountainous areas was introduced. It supplements disadvantages in agricultural production in hilly mountainous areas in order to prevent the abandonment of cultivation in these areas and secure multifunctionality"(MAFF, 2000). The maximum amount that could be reached was 73,000 yen per ha (MAFF, 2001b). This premium was paid for disadvantaged areas such as steep slopes. 
Table 2. Government Budget for Rice Policies in Japan from 2000-2002

\begin{tabular}{|c|c|c|c|c|c|}
\hline Policy Field & & Program (in 100 million yen) & 2000 & 2001 & 2002 \\
\hline \multirow[t]{16}{*}{ Production } & 1 & Comprehensive scheme for agricultural production & 281 & 290 & 327 \\
\hline & 2 & Special scheme for the reallocation of farm land. & 3 & 13 & 8 \\
\hline & 3 & Promotion scheme of system readjustment for farms & 4 & 4 & 3 \\
\hline & 4 & Subsidy for expenditure for farmland adjustment & 1,033 & 1,013 & 848 \\
\hline & 5 & $\begin{array}{l}\text { Subsidy for expenditure for comprehensive scheme of } \\
\text { farmland improvement }\end{array}$ & 299 & 251 & 211 \\
\hline & 6 & National scheme for re-development of farmland & 140 & 128 & 124 \\
\hline & 7 & $\begin{array}{l}\text { Subsidy for promotion scheme for rural areas (promotion } \\
\text { scheme for farmland adjustment) }\end{array}$ & 358 & 345 & 197 \\
\hline & 8 & $\begin{array}{l}\text { Development for new variety breeding and stable } \\
\text { production technique }\end{array}$ & 3 & 18 & 18 \\
\hline & 9 & Direct payment for land diversion & 577 & 668 & 722 \\
\hline & 10 & Expenditure for mutual compensation & 711 & 750 & 750 \\
\hline & 11 & Expenditure for urgent expansion of set-aside & & 64 & 44 \\
\hline & 12 & Scheme of urgent adjustment of rice supply and demand & & 158 & 330 \\
\hline & 13 & $\begin{array}{l}\text { Subsidy for expenditure for smooth adjustment of } \\
\text { establishment of high productivity rice farming }\end{array}$ & 1 & 0.5 & 0.5 \\
\hline & 14 & Aid for fund for rice farming income stabilisation program & 927 & 911 & 865 \\
\hline & 15 & $\begin{array}{l}\text { Urgent scheme of readjustment of regional paddy field } \\
\text { farming }\end{array}$ & & & 200 \\
\hline & & Total of production support & 4,337 & 4,614 & 4,648 \\
\hline \multirow[t]{11}{*}{ Marketing } & 16 & $\begin{array}{l}\text { Storing, transportation and management of } \\
\text { government-purchased rice }\end{array}$ & 528 & 476 & 391 \\
\hline & 17 & Aid for price stabilisation of semi controlled rice & 2 & 2 & 2 \\
\hline & 18 & Scheme for promotion of rice marketing rationalisation & 19 & 12 & 1 \\
\hline & 19 & Scheme for guidance of rehabilitation of rice marketing & 1 & 1 & 0.5 \\
\hline & 20 & Expenditure of assigned research of grain marketing & 0.3 & 0.3 & \\
\hline & 21 & Confirmation of safety of rice & 2 & 1 & 1 \\
\hline & 22 & Program for proper labelling of white rice & & 0.3 & 0.4 \\
\hline & 23 & $\begin{array}{l}\text { Scheme for privatisation of inspection of agricultural } \\
\text { products }\end{array}$ & & 0.3 & \\
\hline & 24 & Aid for special rice storing by agricultural cooperatives. & 160 & 155 & 13 \\
\hline & 25 & Promotion of reform of rice redistribution & & & 127 \\
\hline & & Total of marketing & 712.3 & 647.9 & 535.9 \\
\hline \multirow[t]{3}{*}{ Processing } & 26 & Scheme for technical improvement of rice processing & 0.5 & 0.5 & 0.3 \\
\hline & 27 & Scheme of extension of demand expanding techniques & 0.05 & 0.04 & 0.03 \\
\hline & & Total of processing & $\mathbf{0 . 5 5}$ & 0.54 & $\mathbf{0 . 3 3}$ \\
\hline \multirow[t]{3}{*}{ Consumption } & 28 & Promotion of rice consumption & 46 & 46 & 46 \\
\hline & 29 & Scheme of urgent rice promotion for school lunch & 12 & 12 & 12 \\
\hline & & Total of consumption & 58 & 58 & 58 \\
\hline \multirow[t]{3}{*}{ Disposal of rice } & 30 & Aid for feeding use of rice for agricultural cooperatives & 90 & 80 & 57 \\
\hline & 31 & Discounting for stored rice & 535 & 568 & 277 \\
\hline & 32 & Foreign food aid & 286 & 135 & \\
\hline & 33 & Urgent food assistant for North Korea & 48 & 59 & 97 \\
\hline & & Total of disposal of rice & 959 & 842 & 431 \\
\hline & & Total Rice Policy Cost & 6,067 & 6,162 & 5,673 \\
\hline
\end{tabular}

Source: MAFF (2002): Internal Committee Paper No. 1. Tokyo. (in Japanese). Translated by S. Oda and T. Murata 
The implementation period is from 2000 to 2004 .

The income stabilisation program (No. 14) is comparable with the US system of deficiency payments in the sense that it compensates farmer for incurring losses. The major difference is the calculation of the price gap that qualifies for payments. If the rice price drops below the previous three years average price level, 80 per cent of the price gap is compensated from a fund. Two thirds of the contributions to the fund come from the governmental budget and the farmers contribute one third. The sum of all production support related costs totalled 461.4 billion yen and shows an increasing tendency in the surveyed time period. Measures summarized in the second group are related to marketing and storing of rice. By far the most important cost position in this category (16-25) is the storing, transportation and management of governmental rice (16). Costs were decreasing over the last three years due to a decrease in the government purchase price and the total amount purchased by the government. For the same reason the costs for the group "disposal of rice" (30-33) decreased substantially.

Consumption measures (28-29) focused mainly on the promotion of rice to prevent a further decline in domestic consumption and maintained the subsidies for rice used for school lunches.

Finally, 842 billion yen were allocated for the disposal of rice that includes subsidies to farmers that use the rice to feed animals (30), to subsidise the price for rice released from storage (31) and for food aid most of which was granted to North Korea (32-33). In response to the difficulties of the prolonged over-supply situation, which was not corrected by the production adjustment, MAFF proposed fundamental changes in the current rice crop management system in late 2001. A major component of the proposed measure is the shift from the current method of production area-based allocation to a production volume -based allocation.

Total domestic policy measures in 2001 were higher than in the previous year, but in decline compared for the planned expenditure for 2002 . As the 2002 figure is just a proposal it cannot be interpreted as a trend to less government spending towards the rice sector. However, according to Murata (Personal Interview at Kyushu University, Fukuoka, 2002) and MAFF (2002b) it can be expected that the overall amount spent on rice support schemes will not change substantially in the next few years, mainly due to limits in the agricultural as well as the overall governmental budget. Commitments under the WTO to reduce the budget are highly unlikely, as most of the measures are claimed to belong to the green and blue box (Personal Interview with Professor Murata, T. at Kyushu University, Fukuoka, 2002).

\section{Major Problems of the Japanese Rice Sector}

The international competitiveness of Japanese rice farms is very low due to political inflexibility and legislative obstacles. Furthermore, land scarcity and high land prices are major impediments for improving the productivity of rice farming in Japan.

Tenancy laws and the exclusion of joined stock companies from farming operations still hinder large scale farming operations. Some tenancy arrangement laws actually discourage land sales and subsequent farm consolidation (Bull, 2001, p. 16). But, although generally deemed necessary, they are as difficult to introduce as changes in trade policies, because wealth is based on land value and rent income is quantitatively very important for 
many people who are politically well represented (Meer and Yamada, 1990, p. 162). The strong political power of agricultural interest groups and landowners has been widely discussed (e.g. George, 2000).

Another point of criticism is the fact that inefficient part-time farmers get the same support as full-time farmers. In addition part-time farming can give significant additional tax benefits, even to people whose income is largely obtained from non-agricultural sources. There are support arrangements in place that give better pensions to owners of farmland and thus encouraging the aging of the farm population retain their farmland (Bull and Roberts, 2001, p. 17).

A further major reason that hinders political reforms is the fact that the rural votes weigh much heavier than urban votes, because the adjustment of electoral districts lags behind the changes in population distribution. For lower house elections, the average rural vote is worth three urban votes and for the upper house it is worth up to six urban votes (Boonekamp, 1995, p. 3). It is a fact that the continuously ruling Liberal Democratic Party depends much on rural votes and funding from rural business interests has been an obstacle for adjusting the number and size of election districts, as well as for designing farm policies in which consumers interests are given more weight (Meer and Hayami, 1990, p. 139).

Furthermore it might be worth to mention a point that is deeply connected with the Japanese corporate mentality, which sets the rules for cooperatives. The agricultural production and the distribution of subsidies and governmental payments in Japan are controlled by cooperatives. The policy of these cooperatives is in terms of economic efficiency poor and professional farmers are disadvantaged, because equity considerations among the members a prior to individual progress and benefits. The mutual compensation system might well serve as an example.

1) Future Perspectives. As the consumer carrying the protection system, only spends about 4 per cent of its household budget on rice, no serious opposition to the present system exists. Japanese people are widely convicted that liberalisation is a thing not worth fighting for. The pressure of international trade partners, internal interest groups from export oriented sectors as well as demographically caused structural developments has so far not caused significant changes.

However, in the past consumer purchasing power could grow rapidly because of high economic growth rates. Under these conditions high food prices did not seriously limit the purchasing power and did not meet strong resistance. More consumers have realised that farmers have become wealthier than the average Japanese wage and salary earner, that there is an overproduction of rice that can only be handled with the costly land policy scheme and that food prices in Japan are much higher than abroad. At the same time, trading partners, not so successful in competing with Japan in manufacturing, have put continuous pressure on Japan to open its agricultural markets (George Mulgan, 2000, p. 106). The combined effect could be that the Japanese Government reorients its agricultural policies. But so far other interest groups have not cashed in, and policies remain dominated by rent-seeking interest groups.

An important outcome from the Uruguay Round for agriculture was the opening of a degree of tariff quota access to the Japanese rice market. However, it can be said that the Uruguay Round of multilateral trade negotiations in 1994 has had little effect in liberaliz- 
ing rice trade policy in Japan. Major reasons are the way support is measured under the WTO arrangement ${ }^{1}$ and the way the Japanese Government calculated the tariff level ${ }^{2}$. For the next WTO round no serious commitments can be expected ${ }^{3}$.

2) The New Basic Law- a way forward? With the "Basic Law on Food, Agriculture and Rural Areas" of 1999, the Government of Japan has formulated its future vision of the agricultural sector in Japan. In addition, it has prepared a Negotiating Proposal for the upcoming WTO Round in Doha. Both papers can be summarised under the following 6 objectives:

$>$ Increase of self- sufficiency ratio from 40 per cent to 45 per cent in terms of calories and maintenance of self- sufficiency in rice

$>$ The preservation of the multifunctionality of agriculture (flood mitigation, rural employment, landscape)

$>$ Ensure food security

$>$ Secure farm income, parity of income distribution

$>$ Improvement of the competitiveness of Japanese agriculture

$>$ Consideration for developing countries

The food self-sufficiency ratio (point 1) in Japan showed sharp decreases during the period from 1965 to 2000 , down from 73 per cent to 40 per cent on a calorie supply basis. This downward trend can also be observed on the level of the different commodities as shown in figure 6 . This self-sufficiency performance is the lowest in the developed world, making Japan heavily dependent on food imports.

The major factors responsible for this phenomenon are the decrease of consumption of rice, which is a Japan self-sufficient item and a dramatic increase in imports of feed grains and oilseeds that is caused by increased consumption of animal products (MAFF, 2000). Despite the general trend, self-sufficiency rates in rice have been maintained around 100 per cent in the past decades. However, there is little doubt that attempting to reverse this trend has been a factor promoting the prolonged level of high domestic support.

A major impediment to trade negotiations is the increasing emphasis that Japan is placing on the multifunctional nature of agriculture. Multifunctionality of agriculture is a concept, which explains that agriculture is an economic activity that not only produces food and fibre but also creates both tangible and intangible values, which are embodied in various ways in each country (OECD, 1998). Economic justifications of the multifunctional character are drawn from aspects like the "joint production", the "public good aspect" and the "external effects" of agriculture. Claimed benefits of multifunctionality include environmental values, rural amenities, cultural values, rural development and rural employment (OECD, 1998). In the special case of the Japanese rice production,

\footnotetext{
${ }^{1}$ WTO uses the Aggregate Measure of Support (AMS), which is closer to political compromises than to economic considerations. For more information see OECD (2001b): Agricultural Policies in OECD Countries: Monitoring and Evaluation. OECD. Paris and Bull and Roberts, 2001, p. 29.

${ }^{2}$ The tariffication of rice was surrounded by controversy because the tariff equivalent was based on the price gap between different qualities of domestic and imported rice. see Bull and Roberts, 2001, p. 29

${ }^{3}$ See the Negotiating Proposal of Japan: MAFF (2001a): Negotiating Proposal by Japan on WTO Agricultural Negotiations. Ministry of Agriculture, Forestry and Fishery. Tokyo. http://www.maff.go. jp/wto/wto_nihon_teian_e.htm, http://www.maff.go.jp/wto/wto_nihon_teian_e.htm
} 


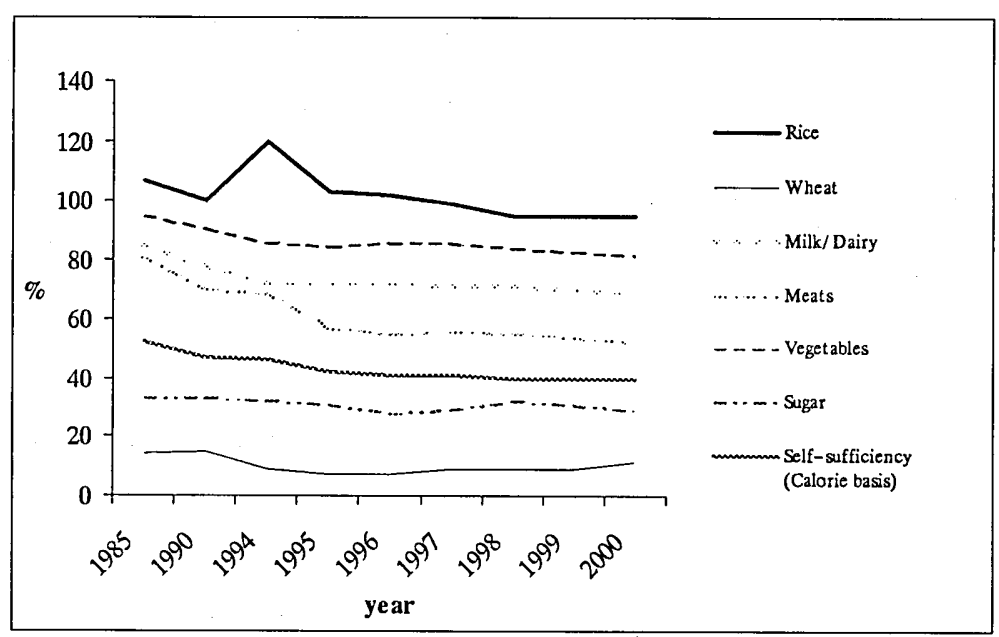

Source: MAFF 2001

Fig. 6. Japan's self-sufficiency ratios in commodity groups.

multifunctional roles demonstrated through production activities in rural areas include roles to preserve national land, foster water resources, create scenic landscapes, mitigate floods and ensure rural employment (MAFF, 2001a), whereas the latter two are argued to be the main spill over benefits of rice production in Japan.

The food security aspect might be Japan's major concern. Food security is defined by the FAO as "the ability of all people at all times to have physical and economic access to sufficient, safe and nutritious food to meet their dietary needs and food preferences for an active and healthy life" (FAO, 1996). However, the Japanese government understands food security in the first place as a means to secure a stable domestic food supply, which practically means to increase domestic production first and then assure the availability of stable imports and proper stockpiles. According to MAFF, 80 per cent of Japanese people indicated the apprehension of this view towards the future prospect of food security in Japan. The reason can be mainly found in the isolated geographical location of Japan and the historical background of its relation to neighbouring countries. To achieve this kind of food security "it is necessary to secure and enhance food supply capabilities by securing and improving agricultural land and securing and training farmers as well as to improve the information collection system and diversify risks by importing from several countries"(MAFF, 2000). The annual report of MAFF of the year 2000 further states that food security is also necessary to guarantee the minimum domestic supply in the event of an emergency. In the way food security is defined as the safety of food in terms of health concerns, the GMO (biotechnology) issue displays another recent development in world trade that may cause further segmentation. Japan as well as South Korea and the EU are currently drafting new regulations for GMO imports. Both Japan and the EU have proposed new labelling regulations.

The improvement of the competitiveness of Japanese agriculture has been a prime 
policy goal over the last 40 years, but not one that has been blessed with a lot of success.

Another target, to secure farm incomes and an equal income distribution aims mainly to keep rural areas inhabited and by providing general support to farmers as a basis of agricultural production.

However, the New Basic Law for agriculture does not appear to provide much more than a prescription for maintenance for the status quo. Nevertheless, one article of the law (article 30) indicates that the "state shall take necessary measures for allowing the prices of farm products to form appropriately, reflecting the real supply- demand situation and quality evaluation, in order to promote agricultural production responsive to consumer demands". At the same time, however, it provides that "the state shall take necessary measures for mitigating the adverse effects of significant price changes of farm products on farm management". Taken at face value, this second provision could negate the effects of market-based reforms on Japanese production that might be construed to flow from the first.

In the following we will show that the rice policies in place are not the best means to reach these targets.

\section{MODEL}

Arguments in favour of trade liberalisation are based on two fundamental ideas in trade theory. One is that the size of the global economy is maximised, when each country focuses on producing and exporting the goods and services that they can produce and deliver most efficiently, and importing the goods and services that are produced less efficiently domestically (theory of comparative advantage). The other is that a world trade system that is undistorted by government intervention will deliver price and profit signals that lead to a globally efficient pattern of production. Put another way, when comparative advantage is the sole basis of trade, the allocation of resources cannot be altered in any way to improve the economic well being in the trading system (Caves and Jones, 1985).

The world economy however is characterised by government intervention that is often in favour of inefficient sectors for reasons previously discussed. That means, sectors where countries do not have a comparative advantage. This moves productive resources away from the optimal usage, resulting in higher cost of living, lower income and lower economic growth. Once the distorting policies are in place it is very difficult for them to be removed (Andersen, 1998). Under these circumstances, trade liberalisation and more generally the removal of market distortions can be expected to translate into high economic growth performance. Another important finding in the literature is that countries can benefit from unilaterally reducing their own trade barriers without waiting for others to open up their markets. Within a unilateral setting, the most important effect of liberalisation occurs when market forces take a greater role in allocating scarce resources to the most profitable usage and competition compelled firms to innovate and adopt cost saving measurers. This factors act to increase national income (Harrison, Rutherford and Tarr, 1995, Bull , 2001). 


\section{Model Specification}

The Consumer Producer Surplus Model is used for the quantitative determination of the welfare effects of alternative liberalisation scenarios. With this comparative framework welfare effects on producer, consumer and governmental budget in Japan can be determined ${ }^{4}$.

Despite the static nature of the framework we made some efforts to improve the quality of the results. Using only the short-run competitive model to analyse changes to trade regimes is too simplistic. Therefore it is necessary to take into account the dynamic forces that are put in motion by a change of the trade regime. Quantitative differences arise mainly because the supply response to a change in the domestic price is larger in the long run. The model adopts this fact by using short-term and long-term elasticities of supply.

Second, the small country case seems unsound for Japan given the fact that Japan will import a considerable amount of Japonica rice compared to the total amount traded on the world market. According to a research of Koo the world market price is likely to rise by 20 per cent with a liberalisation of the rice market. This prediction takes not only a market opening of the Japanese rice sector into account but includes a liberalisation of major Japonica rice consuming and producing countries like Korea and Taiwan, which means the predicted change of the world price can be seen as the minimum level that might occur. However, the model adopts this fact by using a 20 per cent higher c.i.f. price compared to the baseline in the calculation for the total liberalisation scenario.

For the calculation of trade measures the difference between the internal price and the c.i.f price was calculated by using the average prices of the general auction as the internal price and the average outcome of the SBS tenders for Japonica rice as the c.i.f price. With the model we run 2 scenarios:

\section{Scenario 1: Free Trade}

- Abolishment of import quota (MAA) and import tariffs

- No domestic support measures

Scenario 2: Partial Liberalisation

- Abolishment of import quota (MAA)

- $50 \%$ reduction of import tariff

- Domestic support measures unchanged

Each of the 2 scenarios is run in a short-term and long-term perspective. In table 3 and 4 welfare calculations for these partial and total liberalisation scenarios are compiled, whereas table 3 represents a short term reaction using a short term elasticity of supply of 0.45 and table 4 shows the results using a long term elasticity of supply of $0.7232^{5}$. In both cases the world market price is supposed to rise by 20 per cent under free trade. Tariff levels, prices and quantities in the baseline scenario represent levels in 2001. Data are derived from MAFF sources.

\section{Quantitative Effects on Production, Consumption, Welfare and State Budget}

Under the free trade scenario, rice production is estimated to decline from the

\footnotetext{
${ }^{4}$ The theory of applied welfare economics and partial equilibrium models is not discussed in detail as it can be found elsewhere (e.g. Just et al, 1982, Gaisford and Kerr, 2001).

${ }^{5}$ Elasticities are derived from Fujiki, 1998 and Osaki, 1999, Kako, Gemma, Ito, 1997
} 
Table 3. Welfare Calculations for the Japanese Rice Market (Short Term)

\begin{tabular}{lrrr}
\hline \multicolumn{1}{c}{ Short Term } & Situation 2001 & Free Trade & Partial Liberalisation \\
\hline Quantity Domestic Output (t) & $9,057,000$ & $5,283,480$ & $8,645,132$ \\
Quantity Domestic Consumption (t) & $9,000,000$ & $9,790,113$ & $9,118,235$ \\
Imports (t) without tariff & 100,00 & $4,656,633$ & 0 \\
Imports (t) with tariff (34lyen/kg) & 0 & 0 & 0 \\
Imports (t) with tariff (170yen/kg) & 0 & 0 & 623,104 \\
Change government budget & & $598,553,300,000$ & $116,619,979,050$ \\
Change of consumer surplus & & $1,722,762,107,505$ & $248,582,189,038$ \\
Change of Producer surplus & & $-1,897,665,378,392$ & $-244,005,435,226$ \\
Total net welfare changes & & $423,650,029,113$ & $121,196,732,862$ \\
Total net welfare changes (US\$) & & $3,472,541,222$ & $993,415,843$ \\
Total net welfare changes (\%GDP) & & 0.07 & 0.02 \\
\hline
\end{tabular}

Source: Own Calculation

Table 4. Welfare Calculations for the Japanese Rice Sector (Long Term)

\begin{tabular}{lrrr}
\hline \multicolumn{1}{c}{ Long Term } & Situation 2001 & Free Trade & Partial Liberalisation \\
\hline Quantity Domestic Output (t) & $9,057,000$ & $2,573,254$ & $8,336,424$ \\
Quantity Domestic Consumption (t) & $9,000,000$ & $9,790,113$ & $9,120,390$ \\
Imports (t) without tariff & 100,00 & $7,366,859$ & 0 \\
Imports (t) with tariff (341yen/kg) & 0 & 0 & 0 \\
Imports (t) with tariff (170yen/kg) & 0 & 0 & 933,966 \\
Change government budget & & $598,194,000,000$ & $189,798,732,404$ \\
Change of consumer surplus & & $1,722,762,107,505$ & $253,141,845,323$ \\
Change of Producer surplus & & $-1,625,242,501,127$ & $-245,003,020,362$ \\
Total net welfare changes & & $695,713,606,378$ & $197,937,557,365$ \\
Total net welfare changes (US\$) & & $5,702,570,544$ & $1,622,438,995$ \\
Total net welfare changes (\%GDP) & & 0.12 & 0.03 \\
\hline
\end{tabular}

Source: Own Calculation

9,057 million tons in 2001 to about 5.3 million tons in the short and to 2.6 million tons in the long run, thus causing a significant drop in the self-sufficiency rate to 55 per cent and 28 per cent, down from 95 per cent in the baseline. At the same time, domestic consumption increases to 9.79 million tons leading to an increase of imports to 4.7 and 7.4 million tons. Due to lower internal prices and slightly growing demand, the change in consumer surplus in the long as well as the short-term amounts to about 1,722 billion yen per year, which is equal to about 13,000 yen per year and per inhabitant. Due to adjustment effects, producer losses are with 1,625 billion yen lower than in the short run with 1,898 billion yen compared to the base line. Overall welfare changes in the short-term amount to 423 billion yen or 0.07 of Japans GDP of 2000 . In the long run, the model calculated welfare gains of 695 billion yen or 0.12 per cent of GDP.

The partial liberalisation scenario does not create as drastic changes in domestic production and consumption and indicates that even a 50 per cent tariff reduction as an possible outcome of the upcoming WTO negotiations would not put significant pressure on Japanese rice farmers. The model predicts that the supply of rice by Japanese 
producers will fall by 420,000 tons in the short-term and 720,000 tons in the long term. As can be expected that the whole additional import quantity could be diverted to industrial use and therefore not compete directly on retail level, this scenario would not influence the domestic competition significantly. However, the consumer surplus could be 253 billion yen in the long run.

With a tariff level of around 190 yen per kg no rice is imported any more. That implies, given 2001 prices and exchange rates that concessions of tariff reductions below 45 per cent would not influence rice trade in Japan, which means that a reduction of 36 per cent that might be the starting point of the Japanese Government in upcoming WTO Negotiations would not affect imports and domestic production at all.

The effects expected from liberalisation on the government budget are under both scenarios substantial. Under free trade and without the presence of policy measures, governmental income from tariff revenues and mark-up revenues ceases. However, the gain caused by saving 616 billion yen for the domestic rice policy measures leads to an overall change of the governmental budget of 598 billion yen.

Under the partial liberalisation, mark-up revenues are substituted by tariff revenues. As the imported quantity of rice is expected to rise, governmental income from tariffs is considerably higher leading to a reduction in the budget deficit of 117 billion yen in the short run and 190 billion yen in the long run. Tariff income under a tariff rate of 170 yen per $\mathrm{kg}$ in the long term is equal to $(933,966 \mathrm{t} \times 170 \mathrm{yen})=158$ billion yen and in the short term to 107 billion yen.

Moreover, budgetary effects not included in the calculation are assumed to be substantial under free trade. As an example it can be assumed that the administrative costs caused by the Food Agency that almost exclusively deals with rice policy and state trading can be expected to fall dramatically.

However, the agricultural budget is limited and cuts in this budget are more likely than substantial increases. This fact must be thoroughly considered when thinking about policy alternatives. The argument is especially true for the Japanese rice sector. As most of the support comes from trade measures, the consumers largely carry the costs for agricultural support. A potential alternative of current policies would be a change to a direct payment system. Major advantages of the system are besides less market distortion the possibility of a more direct allocation of money according to prevalent policy goals. But even as it can be shown that the direct payment system is more efficient in terms of overall welfare, it puts a considerable burden on the government budget. Keeping this fact in mind, we develop an example for the introduction of a direct payment system. But first we look at the effects of the opening of the rice market on multifunctionality, income distribution and developing countries, having always in mind the targets of the Japanese Government.

\section{LIBERALISATION AND THE TARGET SYSTEM OF THE JAPANESE GOVERNMENT: A CONTRADICTION OR A WAY FORWARD?}

\section{Effects on Multifunctionality}

As shown in the above calculations, liberalisation of the rice market leads mainly to a decrease in domestic production and producer income on the production side. On the 
consumption side it causes an increase in imports and real income of consumers and taxpayers. These changes that vary with the degree of market opening have impacts on the multifunctional aspects of rice farming related to the total quantity of rice produced, the total land under cultivation and the rice price in the form of both- positive and negative- externalities.

A general criticism of claimed spill-over effects from rice production in Japan is that all rice in Japan whether produced in paddies or upland fields, whether produced in the suburbs of Tokyo or in the countryside or cultivated by commercial farmers or part-time farmers, is heavily supported, thus regardless of its positive or negative effects. From the perspective of neoclassical trade theory however, support payments directly related to the desired effect are the most efficient means of distribution. Most of the benefits claimed by the supporters of the concept of multifunctionality as a basis against rice trade liberalisation are only indirectly related to agricultural production. In these cases, subsidising agricultural production is unlikely to enhance positive spillover because the subsidy is not directly targeted at the spillovers themselves.

1) Effects on Food Security. Probably the most important reason for protectionist measures of the Japanese rice policy is the stability and security of supply. However, contrary to the official definition used by the $\mathrm{FAO}^{6}$, for the Japanese Government food security and self-sufficiency seems to be same thing. While a sufficiency ratio of 95 per cent in rice is pursued, this ratio would drop under the partial liberalisation scenario to 90 per cent and under the total liberalisation to 28 per cent. It must be kept in mind though that these figures neglect the fact, that Japan is highly dependent on input imports such as fertilizer and fuel, thus making announced self-sufficiency ratios unrealistic. In 1997 for example, of the 1.5 million tons of fertilizers used in Japan, 64 per cent were imported (FAO, 1999). Dependency on imports are thus not reduced by keeping domestic rice production, but is simply transferred from the end product to the factor inputs.

Food security does not necessarily rely on domestic production. It would only be under abnormal circumstances, such as a war or a major coordinated trade embargo that Japans food imports could be threatened. But the further protection of high cost domestic industries such as the rice sector would do little to secure supplies for more than a short time if trade flows were interrupted. This is because much of Japans production is based on imported inputs. Instead of being a threat to food security, food trade with many countries could actually reduce any potential impacts on food supplies in the event of a conflict or embargo and so would actually improve food security in Japan (Bull and Roberts, 2001, p. 74).

2) Effects on the Environment. Multifunctional roles demonstrated through rice production activities in rural areas include roles to preserve national land and the national environment, foster water resources and mitigate floods (MAFF, 2001a). The Japanese government consequently concludes, that with a decrease in rice production the above spill over effects expected from rice cultivation is reduced as the production is reduced. But the question arises, if rice production is the best means to promote these positive

${ }^{6}$ FAO (Food and Agriculture Organisation) (1996): Rome Declaration on World Food Security and World Food Summit Plan of Action. Rome. 
externalities and what kind of negative environmental externalities is associated with rice production.

Falling rice prices in Japan are likely to result in a decrease of the use of input factors due to a change in the optimal intensity of the production. Less use being made of farm chemical inputs that pollute the air, soil and water. Lower use of irrigation water would reduce soil salinity problems. In fact, the inflated price paid to Japanese rice farmers encourages them to safeguard their crop against any small risk of decreased yield. As a consequence, in 1993, the total worldwide rice insecticides market was US $\$ 1.1$ billion, of which 34 per cent was spent in Japan, although Japan produces less than 3 per cent of the world's rice (FAO, 1999).

Paddy rice in Japan is especially given credit for important spill over effects in flood mitigation and the prevention of soil erosion. However, it must be taken into account that rice is not the only means to reach these goals. Forests can play a similar role. Even if it can be demonstrated that cultivated paddy fields are the most direct and least cost form of providing flood mitigation benefits, the most efficient way is to pay farmers based on their capacity to maintain specific paddy fields as water buffers. Payments would be directly related to the contribution of the fields to flood mitigation and would be made only to producers that provide the spill over effect of flood control, based on the degree of water buffering provided by paddy maintenance or alternative activities (Roberts et al, 1999).

Finally, it seems untrustworthy when the Japanese MAFF, traditionally dominated by conservative farm lobby groups and opposed to environmental politics (George Mulgan, 2000, p. 6) now promote the protection of the environment.

\section{Effects on Domestic Income Distribution}

In 2001, the average farm household income ranged above the average income of urban households (MAFF, 2001a). Changes of that ratio under trade liberalisation for rice can be expected, as the significance of rice- 75 per cent of the farms growing rice on 40 per cent of the agricultural land-is high. However, to assess the effects on individual welfare three major facts must be considered. Firstly, rural households generate only 30 per cent of their income from agricultural activities, because rural economies are not necessarily dominated by agriculture. In Japan, many rural areas are adjacent to urban areas and have numerous non-farm as well as farm activities. As a matter of fact the share of agricultural employment in predominantly agricultural areas is only 14 per cent (Michelman et al, 2001, p. 246). Secondly, over half of the farmers in Japan are aged 65 or more, which means that those people are supplemented by pension funds and will give up their farming activities in the short to medium term, resulting in a substantial decrease of agricultural labour force in Japan. Finally, a substantial reduction of rice prices would result in land price decreases thus making other crops such as vegetables and fodder crops more profitable. Such a change is likely to provide better opportunities to enlarge the scale of operations of more productive farmers.

\section{Effects on Developing Countries}

Internationally producers from rice producing countries would widely benefit from an opening of the Japanese rice market. The benefits come from increasing export pos- 
sibilities as well as from increasing world market prices. Especially countries already engaged in rice trade with Japan such as China can be expected to profit from a freer trade. Generally, a rice market opening would make agricultural production in developing countries more profitable, increase the demand for farm labour and increase rural wages. Marginal workers could be attracted into the commercial sector, leaving behind subsistence practices on hillsides and resulting in less deforestation and soil degradation, particularly on sloping lands.

\section{CONVERSION TO A COMPREHENSIVE DIRECT PAYMENT SYSTEM}

The results of this paper clearly support the thesis that the rice policies in Japan currently in place are not suitable to reach environmental, distributional and food security related goals as formulated by the Japanese government.

Economic theory suggests that payments directly targeting the problem are the most efficient policy choices. The compensation principle of Kaldor and Hicks states that policy B is preferred to policy A if, in the move from policy A to policy B, everyone can be potentially be better of. This measure can be directly employed in performing the direct compensation test. In the total liberalisation scenario consumers gain enough to compensate the producers. Generally, all market-opening options are preferable when taking consumers and taxpayers as one group, as with compensation payments everybody can be made better off compared to the baseline situation. The Pareto criterion says that a policy change is socially desirable if by the change everyone can be made better of or at least some are made better off while no one is made worse of. This principle also implies the willingness of the potential winners to compensate the losers. The rule of Tinbergen states, that for each political target an own policy measure is required to achieve the goals most efficiently.

As an example of the introduction of a direct payment system, we analyse the simple case of the compensation of a defined target group of farmers for the incurring losses caused by lower prices.

According to the long-term target of the Japanese Government to improve the structure and the competitiveness of rice farmers our example focuses on the group of farmers that have the potential to make rice farming in Japan more efficient and reach international competitiveness. Practically, we concentrate the direct payment system on farmers fulfilling the following criteria.

$>$ Farmers under 65 years,

$>$ Farm income is more than 50 per cent of total income and

$>$ The farmer's activity on the farm is more than 60 days per year.

36 per cent of total rice supply in Japan is produced by this group (MAFF, 2001b). Given that case, these farmers get

$$
9,057,000 \times 0.36 \times(328,035-88,164)=820 \text { billion yen }
$$

as compensation, whereas $9,057,000$ represents the quantity of domestic production and the figures in brackets represent the difference between the supply and the import parity price.

The new system would lead to the above outlined advantages of free trade such as comprehensive welfare gains and the improvement of allocative efficiency. The elabora- 
tion and introduction of a more detailed program could take multifunctional and distributional aspects into account.

\section{SUMMARY AND CONCLUSION}

The Japanese rice sector represents the typical case of a highly protected agricultural market in an industrialised country.

Rice prices in Japan for the prevalent Japonica rice were 3.5 times higher than in major exporting countries like the US and China. These high prices are caused by an effective import regime that successfully prevents foreign rice to compete with domestically produced rice. Although Japan agreed in the Uruguay Round to partially open its market under the Minimum Access Scheme, effects on the domestic market are marginal as most of this imported rice is diverted to food aid or sold directly to the food processing industry. Outside the import quota, Japan has set a tariff of 341 yen per kg rice, which is prohibitively high, given the fact that domestically produced rice averaged around 270 yen per $\mathrm{kg}$. As could be shown in this paper, even a reduction of the of the present tariff level of 50 per cent would not have significant impacts on the Japanese rice trade balance.

Most of the support for Japanese rice producers comes from price support. Obviously, the high domestic price has a major impact on national welfare. It leads not only to higher costs for domestic consumers, but it also creates overproduction, inefficient farms, and contributes to environmental problems. In 2001, 616 billion or 21 per cent of the total MAFF budget was spent for rice policy with over half the amount related to production control programs, government marketing and disposal of rice.

Under a free trade scenario, rice production is estimated to decline from the 9.057 million tons in 2001 to about 5.3 million tons in the short and to 2.6 million tons in the long run, thus causing a significant drop in the self-sufficiency rate to 55 per cent and 28 per cent, down from 95 per cent in the baseline. At the same time, domestic consumption increases to 9.79 million tons leading to an increase of imports to 4.7 and 7.4 million tons. Due to lower internal prices and slightly growing demand, the change in consumer surplus in the long as well as the short-term amounts to about 1,722 billion yen per year, which is equal to about 13,000 yen per year and per inhabitant. Due to adjustment effects, producer losses are with 1,625 billion yen lower than in the short run with 1,898 billion yen compared to the base line. Overall welfare changes in the short-term amount to 423 billion yen or 0.07 of Japans GDP of 2000 . In the long run, the model calculated welfare gains of 695 billion yen or 0.12 per cent of GDP.

A partial liberalisation scenario does not create as drastic changes in domestic production and consumption and indicates that even a 50 per cent tariff reduction as an possible outcome of the upcoming WTO negotiations would not put significant pressure on Japanese rice farmers. The model predicts that the supply of rice by Japanese producers will fall by 420,000 tons in the short-term and 720,000 tons in the long term. Furthermore, it can be expected that the whole additional import quantity could be diverted to industrial use and therefore not compete directly on retail level. However, the consumer surplus could be 253 billion yen in the long run. Regarding upcoming WTO Negotiation it could be shown that with a tariff level of around 190 yen per $\mathrm{kg}$ no rice is 
imported any more. That implies, given 2001 prices and exchange rates that concessions of tariff reductions below 45 per cent would not influence rice trade in Japan, which means that a reduction of 36 per cent that might be the starting point of the Japanese Government in upcoming WTO Negotiations would not affect imports and domestic production at all.

The effects expected from liberalisation on the government budget are under both scenarios substantial. Under free trade and without the presence of policy measures the government saves 598 billion yen.

However, there are several reasons for the maintenance of border protection and arguments that seriously hinder policy reform though welfare economics suggest the opposite. Tenancy laws, election modalities, inflated land prices and the strong influence of agricultural interest groups stand in the way of the modernisation of the agricultural sector. As the consumer carrying the protection system, only spends about 4 per cent of its household budget on rice, no serious opposition to the present system exists. Japanese people are widely convicted that liberalisation is a thing not worth fighting for. The pressure of international trade partners, internal interest groups from export oriented sectors as well as demographically caused structural developments has so far not caused significant changes.

On the contrary, the new agricultural policy of Japan attaches great importance to food security, multifunctional aspects of agriculture and the parity of rural- urban income distribution as constituted in the Basic Law for Agriculture and the Negotiating Proposal of Japan for the WTO Negotiations. An analysis of the effects of liberalisation shows that the current rice policy system is not the best means to reach the set targets. On the contrary, the Japanese rice policy appears to use the multifunctional arguments only as pretence to justify its protectionist interventions and to be a blunt instrument aimed at promoting agricultural production rather than a targeted instrument that is aimed directly at the externality. Practically, food security and self- sufficiency is, contrary to the FAO definition, basically the same thing in Japan. The official target is to increase the national self-sufficiency ratio by 5 per cent to 45 per cent over the next years. Claimed environmental spillover effects of paddy farming are promoted without regarding negative external effects, namely caused by the high intensity of production that occurs under the high price policy. Other means of reaching environmental goals could e.g. feature the conversion of paddies to pastures or forests. Income parity considerations must take into account that in 2001 the average farm income was higher than the urban income and the fact that 70 per cent of the rural income stems from non-farm activities.

However, even if it could be proved that rice farming is the best means to reach the set targets, economic theory suggests that payments directly targeting the problem are the most efficient policy choices. A direct payment system that targets a selected group of full time farmers however, would lead to significant welfare gains and to budgetary costs of 820 billion yen. That means the new system would require an increase in governmental spending of 222 billion yen, up from 616 billion yen. But especially in times where economic growth is stagnating the option of direct compensation payments and thus an increase in governmental budget spending is not an attractive alternative for politicians.

The future development of Japans agriculture in the new millennium depends largely 
on three major factors: general economic development, trends in world agriculture, trade and agricultural policies. As the first two factors are largely exogenous, agricultural policies can play a crucial role. These policies are the outcome of an interactive process in which domestic and increasingly international forces come together. However, by the time of this report there was no evidence for substantial changes in Japanese rice policies. Neither domestic consumers nor international commitments are expected to significantly change the system. The AMS system used in the WTO Negotiations is closer to political compromises than to economical considerations thus leaving enough space for each country to justify its protection policy. This political reality that is prevalent in many countries shows that the opening of markets and the liberalisation of trade cannot be achieved by economic rationales alone, but require an international willingness for political reform and global justice.

\section{REFERENCES}

Anderson, K. and Hayami, Y. 1986 The Political Economy of Agricultural Protection. East Asia in anInternational Perspective. Allan and Unwin, Sydney.

Boonekamp, L. 1995 Agriculture in Japan: Current Issues and Possible Implications of the Uruguay Round Agreement. National Research Institute of Agricultural Economics. Ministry of Agriculture, Forestry and Fishery, Tokyo.

Breisinger, C. and W. Grosskopf 2002 Policy Analysis of the Liberalisation of the Agricultural Market of an Industrialised Country-A Case Study of the Japanese Rice Sector. Master's Thesis. University of Hohenheim, Germany.

Bull, T. and I. Roberts 2001 Agricultural Trade Policies in Japan. The Need for Reform, ABARE Research Report 01.5, Canberra.

Caves R., Jones, R. 1985 World Trade and Payments: An Introduction. 4 th ed. Little, Brown and Company, Boston and Toronto.

Dyck J., Childs N., Ackerman K., Skully D., Hansen S 1999 Rice Tarifs in Japan: What does it mean for Trade? Agricultural Outlook, Economic Research Service. US Department of Agriculture. Washington D.C.

FAO (Food and Agriculture Organisation) 1996 Rome Declaration on World Food Security and World, Food Summit Plan of Action, Rome.

FAO 1999 FAOSTAT Agriculture Database, Rome. http://apps.fao.org/cgi-bin/nph-db.pl.subset= agriculture

FAO 2001 Rice Market Monitor, Commodity and Trade Division, FAO. Rome. http://www.fao.org/es ESC/esce/escb/rice/monitore/ricemone.htm

Fujiki, H. 1998 Japanese Rice Market Liberalisation: A Competitive Equilibrium Approach. Working Paper, Kyoto Institute of Economic Research, Kyoto.

Gaisford, J. and W. Kerr 2001 Economic Analysis for International Trade Liberalisation, The WTO and Agricultural Trade, Edward Elgar. U.K.

George Mulgan, A. 2000 The Politics of Agriculture in Japan. Nissan Institute:Japanese Studies Series, Routledge, London and New York.

Huang, David, Duff 1991 Rice Production and Consumption in Asia, FAO, IRR Publication. http://www.fao.org/inpho/vlibrary/t0567e/T0567E04.htm

Just, E. et al. 1982 Applied welfare economics and public policy, Englewood Cliffs, Prentice-Hall, New York.

Kako, T., Gemma, M., Ito, S. 1997 Implication of the Minimum Access Rice Import on Supply and Demand of Rice in Japan. Agricultural Economics, 16: 193-204.

Koo, W., Taylor R. 1999 Outlook of the World Rice Industry under Alternative Trade Liberalisation Policies in Japan and Korea. Agricultural Economics Report, No. 433. http://agecon.lib.umn.edu/ndsu.html.

Lingard, J. 2001 Multifunctional Character of Paddy Rice Farming in the Republic of Korea: Causes and Consequences of Global Environmental Change. Working Paper, Conference Sept 12-17. Maastricht. 
Netherlands. http://www.econ.unian.it.eaae/program.html-65k

MAFF 2000 Abstracts of Statistics on Agriculture, Forestry and Fisheries in Japan, Statistics and Information Department Ministry of Agriculture, Forestry and Fisheries, Government of Japan.

MAFF 2001a Negotiating Proposal by Japan on WTO Agricultural Negotiations, Ministry of Agriculture, Forestry and Fishery. Tokyo. 4. May 2001

MAFF 2001b Komedas. Report of Agricultural Statitics 2001, Ministry of Agriculture, Forestry and Fisheries, Tokyo

Meer, C. van der and S.Yamada 1990 Japanese Agriculture: A Comparative Economic Analysis, Routledge, London and New York.

Michelmann, H. et al. 2001 Globalisation and Agricultural Trade Policy, Boulder, Co. Lynne Rienner Publications.

Ministry of Management, Home Affairs, Post and Telecommunications 2002 Statistical Tables. www.stat.go.jp/english/data/kakei/index.htm.

OECD 1987 National Policies and Agricultural Trade, Country Study Japan, OECD, Paris.

OECD 1998: Workshop on Multifunctionality. Discussion Paper, OECD Secretariat Agricultural Land Conservation, Paris. http//www1.oecd.org/agr/mf/doc/agrmf1.pdf

OECD 2000 Agricultural Policies in OECD Countries: Monitoring and Evaluation, Paris.

Osaki, S. 1999 A Study on an Alternative Rice Policy in Japan. Master's Thesis of the Department of Agricultural Economics, Kyushu University (in Japanese)

Paggi M. and F. Yamazaki 2001 The WTO and International Trade Prospects. Presentation for the Executive Semina, University of California. http://www.aic.ucdavis.edu/ oa/paggi.pdf

Roberts, I., Podbury, T., Freeman, F. Tielu A., Vanzetti, Andrews, N., Melanie, J., Hinchi, M. 1999 Reforming World Agricultural Trade Policies. Abare Research Report 99.12, Canberra.

Suzuki, N. and H. Kaiser 1998 Market Impacts of Japanese Rice Policies: With and Without Supply Control. Agribusiness, 14(5): 355-362.

Tinbergen, J. 1975 On the theory of economic policy, Amsterdam : North-Holland Press.

USDA 2001 Agricultural Outlook: The Agricultural Situation in the European Union, Washington D. C., www.ers.usda.gov/publications/AgOutlook/Jan2001/-29k

Worldbank 2001 Japan at a Glance, World Bank Group, Washington D. C. http://www.worldbank. orgdata/countrydata/aag/jpn-aag.pdf 